\title{
Tangence
}

\section{Histoire et cinesthésie de l'américanité : l'impossible autobiographie de Gertrude Stein}

\section{Jean-François Côté}

Numéro 42, décembre 1993

Le récit de soi

URI : https://id.erudit.org/iderudit/025792ar

DOI : https://doi.org/10.7202/025792ar

Aller au sommaire du numéro

Éditeur(s)

Tangence

ISSN

0226-9554 (imprimé)

1710-0305 (numérique)

Découvrir la revue

Citer cet article

Côté, J.-F. (1993). Histoire et cinesthésie de l'américanité : l'impossible autobiographie de Gertrude Stein. Tangence, (42), 113-130.

https://doi.org/10.7202/025792ar d'utilisation que vous pouvez consulter en ligne.

https://apropos.erudit.org/fr/usagers/politique-dutilisation/ 


\section{Histoire et cinesthésie de l'américanité: l'impossible autobiographie de Gertrude Stein Jean-François Côté}

"I always wanted to be historical..." écrivait Gertrude Stein en 1946 , tout juste quelques semaines avant sa mort ${ }^{1}$. Préfaçant un recueil de ses cuuvres choisies, elle exprimait ainsi un vœu apparemment accompli, de même que la dette qu'elle devait à son éditeur et ami, Carl Van Vechten, pour avoir rendu cette situation possible, c'est-à-dire lui avoir permis, du fait même de la publication, de constituer, ou de (re)confirmer de nouveau l'existence de son "personnage historique " ${ }^{2}$. Intérêt d'autant plus paradoxal, peut-on croire, qu'il exprimait en réalité, par le biais d'une recherche de reconnaissance universelle, l'inversion radicale de tout ce que le projet de création de Stein, dans son extrême singularité, avait semblé porter et promouvoir en tant que développement esthétique original.

L'histoire en effet, telle qu'elle pouvait pour Gertrude Stein apparaître comme étant inextricablement liée au temps, à la civilisation, à l'identité, mais par le fait même être totalement opposée au présent, à l'imagination, au génie, était en quelque sorte l'antithèse du projet artistique d'une des figures importantes de la modernité esthétique ${ }^{3}$. Témoins de cette position qui rendrait impossible dans ce contexte la narration de soi qu'est l'autobiographie,

1 "J'ai toujours voulu être historique...", Gertrude Stein, Selected Writings of Gertrude Stein, Carl Van Vechten ed., New York, Vintage Books, 1990 (1946), p. vii.

2 Je cite le passage in extenso: "I always wanted to be historical, from almost a baby on, I felt that way about it, and Carl [Van Vechten] was one of the earliest ones that made me certain that I was going to be." (Stein, ibid., p. vii) Stein soulignait également à cette occasion que Van Vechten avait été à l'origine de la publication de Tender Buttons, en 1914, et qu'il avait donc accompagné le développement de son projet d'écriture, ainsi que son "rayonnement historique", presque depuis ses débuts.

3 Sur certains débats entourant cette question non seulement de la place de Stein à l'intérieur du "modernisme" (ou de ce que je préfère appeler pour ma part la modernité esthétique), mais aussi sur la signification de ce mouvement, voir A. Eysteinsson, The Concept of Modernism, Ithaca, Cornell University Press, 1990, p. 90-91. 
114

les deux tentatives autobiographiques inévitablement détournées de Gertrude Stein que sont The Autobiography of Alice B. Toklas et Everybody's Autobiograpby. Comment comprendre alors que l'histoire se pose finalement comme instance véritable de réalisation de soi, comme lieu de confirmation de l'individualité, de la création esthétique, de l'identité personnelle? Comment comprendre l'importance accordée à l'existence d'un tel "personnage historique"? La création esthétique, le "modernisme" de Stein, ne sont-ils pas finalement de simples prétextes à l'expression narcissique et à la renommée individuelle? Ou plus radicalement encore, y a-t-il reconnaissance, dans l'acception de l'"ordre historique" chez Stein, de la faillite du projet de la modernité esthétique? Pourquoi voir alors, dans cette perspective, un problème particulier dans l'écriture de soi qu'est l'autobiographie?

L'examen de cette contradiction entre histoire et esthétique qui passe par le "récit de soi", comme je le propose ici, voudrait au contraire montrer que c'est justement à travers cette tension seulement que peut être compris le projet autobiographique de Gertrude Stein, tel qu'il se définit de manière si étrange à première vue. Projet esthétique d'abord, projet de quête d'identité, de reconnaissance, mais également projet d'interrogation du sens, de la civilisation, du temps présent, du soi, tels que ces termes apparaissent, dès les premières décennies $\mathrm{du} \mathrm{xx}^{\mathrm{e}}$ siècle, être transformés en profondeur dans ce qu'on peut comprendre, comme nous le verrons plus bas, comme étant les implications symboliques de l'idée de "communication".

Pour Gertrude Stein, ce problème se concentre seulement graduellement dans celui de la narration. Réfléchissant sur l'évolution de son projet d'écriture, et sur la place de plus en plus considérable qu'elle faisait au procédé narratif dans ses derniers écrits (et particulièrement Wars I Have Seen et Paris, France), elle relevait, de nouveau vers la fin de sa vie en 1946:

I have done the narration because in narration your great problem is the problem of time in telling a story of anybody. And that is why newspaper people never become writers, because they have a false sense of time... You have as a person writing, and all the really great narration has it, you have to denude yourself of time so that writing time does not exist. If time exists your writing is ephemeral. You can have a historical time but for you the time does not exist and if you are writing about the present the time element must cease to exist. 
[...] There should not be a sense of time but an existence suspended in time. That is really where I am at the present moment. I am still largely meditating about this sense of time. ${ }^{4}$

Nous reconnaissons ici les paramètres fondamentaux du projet esthétique de Stein, héritier direct d'une modernité esthétique qui se définit toujours, comme l'écrivait Baudelaire, dans "[...] le transitoire, le fugitif, le contingent, la moitié de l'art, dont l'autre moitié est l'éternel et l'immuable", mais radicalisé encore dans les formes d'une écriture "cubiste" où se pose avant tout la possibilité d'un "présent continu" (continuous present") ${ }^{5}$; de même, l'opposition si caractéristique contre l'époque et les formes d'écriture ou de communication qu'elle préconise (ici le journalisme), une opposition qui marque une distance réflexive critique vis-àvis de la civilisation du progrès; enfin, la situation du "soi", de l'individu, de la personnalité, et de la possibilité de la relation de son expérience du (et dans le) monde. C'est l'articulation de ces différentes composantes qui situe à la fois la possibilité et l'impossibilité autobiographiques de Gertrude Stein.

\section{Les deux autobiographies}

On connaît le subterfuge par lequel Gertrude Stein écrit sa première autobiographie, The Autobiography of Alice B. Toklas:

4 Gertrude Stein, "Afterword", dans What are Masterpieces, New York, Putman Publishing Corporation, 1970 , p. 103. Je traduis librement la citation, comme toutes celles qui suivront: "J'ai fait de la narration parce que dans la narration votre gros problème est le problème du temps dans le récit d'une histoire de quelqu'un. Et c'est pour cela que les journalistes ne deviennent jamais écrivains, parce qu'ils ont un sens erroné du temps.... Vous avez en tant que personne qui écrit, et toute grande narration possède cela, vous avez à vous défaire du temps de telle sorte que le temps de l'écriture n'existe pas. Si le temps existe votre écriture est éphémère. Vous pouvez avoir un temps historique mais pour vous le temps n'existe pas et si vous écrivez à propos du présent l'élément temps doit cesser d'exister. [...] Il ne devrait pas y avoir un sens du temps mais plutôt une existence suspendue dans le temps. C'est vraiment où j'en suis au moment présent. Je suis encore en train de méditer beaucoup sur ce sens du temps."

5 Charles Baudelaire, "Le peintre de la vie moderne", dans Baudelaire critique d'art, Paris, Gallimard, 1992 (343-384), p. 355. Sur le "cubisme" de Gertrude Stein, voir notamment D. Sutherland, Gertrude Stein, trad. Nicole Balbir, Paris, Gallimard, 1973 (1951), p. 7-28, ainsi que W. Sypher, Rococo to Cubism in Art and Literature, New York, Vintage Books, 1963 (1960), p. 257311. 
116

c'est le point de vue de sa compagne de vie, Alice Toklas, qui sert alors de prête-nom pour relater principalement les épisodes qui composent la vie de Stein à Paris de 1903 à 1932. Tout le récit adopte ce point de vue extérieur, celui d'une altérité réelle mais fictivement personnifiée de façon à faire parler son intériorité factice, qui n'accepte ici le jeu de la substitution que pour s'effacer dans la narration des événements qui concernent plus directement Gertrude Stein (ou encore, en creux, la relation d'Alice Toklas à Gertrude Stein). Double procès de dédoublement donc, où Stein n'est elle-même que par l'emprunt d'une autre vie qui parle d'elle, emprunt par lequel est affirmée en retour sa propre présence en tant que figure qui domine la vie de Toklas, et par lequel est introduite également l'affirmation du génie de Gertrude Stein justifiant l'écriture (auto)biographique ${ }^{6}$.

Il n'y a que ce double procès de dédoublement qui permette à la narration d'être ce qu'elle est, c'est-à-dire une narration au sens usuel du terme, ou en tout cas une narration qui est en apparence, pour la surface du texte, en rupture avec les expérimentations antérieures (de Tender Buttons à As a Wife Has a Cow, ou même encore à celles de The Making of Americans) ${ }^{7}$.

6 La façon dont se présente ce "récit de soi" par personne doublement interposée révèle déjà la singularité du projet. Faisant parler Toklas, Stein écrit en effet: "The three geniuses of whom I wish to speak are Gertrude Stein, Pablo Picasso and Alfred Whitehead. I have met many important people but I have only known three fist class geniuses and in each case on sight within me something rang. In no one of these three cases have I been mistaken. In this way my new full life began. "Gertrude Stein, The Autobiograpby of Alice B. Toklas, New York, Vintage Books, 1961 (1933), p. 5. Je souligne la dernière phrase, puisqu'elle peut être interprétée également autant pour le personnage qui raconte (Toklas) que pour le narrateur réel (Stein), dans la mesure où c'est bien par la reconnaissance d'elle-même en tant que figure du génie établie dans la narration que commence pour Stein cette "new full life".

7 Stein écrit à ce propos: "And then as a joke I began to write the Autobiograpby of Alice B. Toklas and at that moment I made a rather interesting discovery. A young French poet had begun to write and I was asked to translate his poems and there I made a rather startling discovery that other people's words are quite different from one's own and that they cannot be the result of your internal troubles as a writer. They have a totally different sense than when they are your own words... Narrative has a different concept than poetry or even exposition, because you see the narrative in itself is not what it is in your mind but what it is in somebody else's. And so I did a tour de force with the Autobiograpby of Alice B. Toklas and when I sent the first half to the agent they sent back a telegram to see which one of 
Cela est important puisqu'à ce moment est mise en scène clairement une partie des remises en question que comportaient son écriture antérieure; ce n'est que par rapport à un "moi " que situe un "autre que moi" que son propre récit de vie se constitue. À défaut de reconnaître ce procès déjà implicitement à l'œuvre dans les expérimentations antérieures, celles-ci apparaissent comme un immense charivari où l'objet du texte n'est qu'un "jeu de langage" tout à fait gratuit. Au contraire, perçu sous l'angle de ce procès, le projet du texte devient plutôt recherche d'une position d'élocution (ou d'écriture), une position par laquelle ce qui sera dit (ou écrit) ne pourra être confondu avec le langage en général, avec la rumeur de sens qui traverse le monde, partout et constamment, indifféremment des individualités ou des personnalités. Pour Stein, comme elle en viendra à le réaliser pleinement, "[...] talking has essentially nothing to do with creation " 8 , et il s'agit dès lors de confronter cette difficulté qui rejoint le problème du rapport entre les objets (ou le monde), le langage, et l'identité du "soi" - problème donc de la dialectique de l'identité narrative tel que l'a reconnu Paul Ricour ${ }^{9}$, problème qui est posé avec tant d'acuité dans le contexte contemporain.

La deuxième autobiographie de Gertrude Stein mesure ironiquement par son titre la distance parcourue dans la compréhension du rapport qui soutient l'écriture de création: Everybody's Autobiography, c'est ainsi l'uautobiographie de tout le monde", ou en fait l'autobiographie que tout le monde peut écrire une fois qu'est dévoilé le subterfuge du détour par l'autre de l'écriture autobiographique ${ }^{10}$. Tout le monde pris dans le revers du "soi",

us had written it. But still I had done what I saw, what you do in translation or in narrative. I had created the point of view of somebody else. Therefore the words ran with a certain smoothness. "Stein, "Afterword", op. cit., p. 102.

8 "[...] parler n'a essentiellement rien à voir (ou à faire) avec la création". Gertrude Stein, "What Are Master-Pieces and Why Are there so Few of Them $n$, in What are Masterpieces?, op. cit., p. 84.

9 "Ce que suggèrent les cas limites engendrés par l'imagination narrative, c'est une dialectique de la possession et de la dépossession, du souci et de l'insouciance, de l'affirmation de soi et de l'effacement de soi. Ainsi le néant imaginé du soi devient-il "crise" existentielle du soi. "Paul Ricœur, Soi-même comme un autre, Paris, Seuil, 1990, p. 198.

10 C'est le dernier paragraphe de la première autobiographie qui donne la clé du subterfuge. Stein écrit alors: "About six weeks ago Gertrude Stein said, it does not look to me as if you were ever going to write that autobiography. You know what I am going to do. I am going to write it for you. I am going 
ou à l'inverse le "soi" perçu à travers tout le monde, tel est au fond le rapport constitué par la compréhension du lien intrinsèque de l'identité et de l'altérité que met toujours en scène l'écriture. Mais c'est aussi davantage, puisque c'est du même coup la réalisation du fait que la situation engendrée par le génie (ou plus exactement le succès), si elle met bien réellement en place la situation typique du "soi" qui a vraiment quelque chose à dire par sa création, ne cesse d'être également extrêmement troublante pour l'identité même du soi, du fait de cette révélation dans son contexte "mondain"11. En effet, non seulement ici Stein prend-t-elle la parole, mais elle réalise également ce que ce geste comporte d'impersonnalité, et de quelle façon il échappe pour ainsi dire à l'individu lorsque celui-ci est en relation avec le public. Elle écrit justement à ce propos:

At any moment when you are you you are you without the memory of yourself while you are you you are not for purposes

to write it as simply as Defoe did the autobiography of Robinson Crusoe. And she has and this is it." Gertrude Stein, The Autobiography of Alice Toklas, op. cit., p. 252. La deuxième autobiographie commente l'épisode que constitua la première, et surtout le succès qu'elle connut, et qui fit de Gertrude Stein un personnage "public" aux États-Unis. C'est d'ailleurs le succès de cette première autobiographie qui suscita l'invitation faite à Stein de prononcer une série de conférences aux États-Unis en 1934-1935, ce qui allait fournir la matière de la deuxième autobiographie. Dans celle-ci, Stein explique brièvement la situation nouvelle créée à son sens par la première autobiographie: "ALICE B. TOKLAS did hers and now everybody will do theirs. Alice B. Toklas says and if they are all going to do theirs the way she did hers. [...] Anyway autobiography is easy like it or not autobiography is easy for anyone and so this is to be Everybody's Autobiography. Gertrude Stein, Everybody's Autobiography, London, Virago Press, 1985 (1937), p. xxi, xxiii.

11 L'ambivalence de cette situation est exprimée de cette façon par Stein : "I used to say that was long ago in beween I never had thought of going. I used to say that I would not go to America until I was a real lion a real celebrity at that time of course I did not really think I was going to be one. But now we were coming and I was going to be one. In America everybody is but some are more than others. I was more than others." Plus loin, elle rajoute: "If anything is natural enough it is not surprising and then we went out again on an avenue and the elevated railroad looked just like it had ever so long ago and then we saw an electric sign moving around a building and it said Gertrude Stein has come and that was upsetting but on the whole it is natural enough but to suddenly see your name is always upsetting. Of course it has happended to me pretty often and I like it to happen just as often but always it does give me a little shock of recognition and nonrecognition. It is one of the things most worrying in the subject of identity." Gertrude Stein, Everybody's Autobiograpby, op. cit., p. 143-150. 
of creating you. This is so important because it has so much to do with the question of a writer to his audience. One of the things that I discovered in lecturing was that gradually one ceased to hear what one said one heard what the audience hears one say, that is the reason that oratory is practically never a master-piece very rarely and very rarely history, because history deals with people who are orators who hear not what they are not what they say but what their audience hears them say. ${ }^{12}$

Nous apercevons ici la situation dans ce qu'elle peut comporter de critique: la création de soi échappe précisément à l'individu qui en fait pourtant son objet, et si le détour obligé par l'altérité dans la narration permet que se concrétise un "récit de soi", c'est qu'il figure du même coup que cette identité est en somme abandonnée à être ce que l'autre (qu'est par exemple dans ce cas-ci une audience ou un public) en fait; une "identité" qui n'est pas, dans le vocabulaire de Stein, une "entité ", c'est-à-dire une ouvre de création, chef-d'œuvre, produit du génie, mais bien un produit, indifférent ${ }^{13}$. L'autobiographie, malgré le double procès de dédoublement qu'elle met en scène pour pouvoir s'appartenir en tant que "récit du soi", reste après tout l'œuvre de l'autre et non celle du "soi" - du moins dans son existence en tant que "produit" 14 .

12 "ì n'importe quel moment où vous êtes vous vous êtes vous sans la mémoire de vous-mêmes parce que si vous vous souvenez de vous-mêmes lorsque vous êtes vous vous n'êtes pas pour cette raison en train de vous créer [vous-mêmes]. Cela est très important parce que cela a à voir avec la question [du rapport] entre un écrivain et son audience. Une des choses que j'ai découvertes en donnant des conférences fut que graduellement on cesse d'entendre ce que l'on dit pour entendre ce que l'audience nous entend dire, c'est la raison qui fait que l'oraison n'est pratiquement jamais un chefd'ouvre ou très rarement et très rarement l'histoire parce que l'histoire s'occupe de gens qui sont orateurs qui n'entendent pas ce qu'il sont pas ce qu'ils disent mais ce que leurs audiences les entendent dire." Gertrude Stein, "What are Master-Pieces and Why there Are so Few of Them", op. cit., p. 86.

13 Stein écrit à ce sujet: "[...] It is true that the master-piece has nothing to do with human nature or with identity, it has to do with the human mind and the entity that is with a thing in itself and not in relation. The moment it is in relation it is common knowledge and anybody can feel and know it and it is not a masterpiece. [...] It is not extremely difficult not to have identity but it is extremely difficult the knowing of not having identity. One might say it is impossible but that is not impossible is proved by the existence of master-pieces which are just that. They are knowing that there is no identity and producing while identity is not. That is what a master-piece is." Ibid., p. 88, 90-91.

14 Stein écrit notamment à cet égard: "I was almost going to talk this lecture and not write and read it because all the lectures that I have written and 
Qu'est-ce à dire sinon que, dans le tréfonds de l'exploration de cette subjectivité contemporaine loge une indéfectible relation entre identité et altérité, entre le "moi" et l'"autre" (ou dans le "soi-même" ${ }^{15}$ ), et que l'approfondissement de la position de la modernité esthétique telle qu'elle se déploie chez Gertrude Stein renvoie précisément à une problématique de mise à jour de ce rapport qui interroge au plus près la possibilité pour le "soi" de (se) raconter ${ }^{16}$. De (se) raconter en effet, ou de (se) connaître; Freud a souligné à cet égard que le narcissisme fondamental de l'humanité, son amour profond pour elle-même réfléchi dans la cosmologie géocentrique, dans la position de la domination de la culture vis-à-vis de la nature, et enfin dans la possibilité même d'une connaissance autonome de soi, avait été à chacun de ces niveaux l'objet d'une remise en cause radicale par le développement de nos conceptions scientifiques contemporaines - dont évidemment celles de la psychanalyse, pour ce troisième niveau crucial du "connais-toi toi-même». Or si le narcissisme constitue à nos yeux de contemporains une forme pathologique de développement de l'ego (à laquelle Freud associe par exemple des phénomènes tels que l'homosexualité, la mélancolie, ou la

read in America have been printed and although possibly for you they might even being read be as if they had not been printed still there is something about what has been written having been printed which makes it no longer the property of the one who wrote it and therefore there is no more reason why the writer should say it out loud than anybody else and therefore one does not." Ibid., p. 84. Elle remarque ailleurs comment cette situation met en jeu sa propre identité vis-à-vis de celle de son œuvre: "It always did bother me that the American public were more interested in me than in my work. And after all there is no sense in it because if it were not for my work they would not be interested in me so why should they not be more interested in my work than in me. That is one of the things one has to worry about in America, and later I learned a lot more about that", Gertrude Stein, Everybody's Autobiograpby, op. cit., p. 37.

15 Paul Riccur, Soi-même comme un autre, op. cit.

16 En effet, la difficulté du "récit de soi " ne fait dans ce contexte que redoubler la difficulté du "récit " tout court, difficulté qui problématise on le sait toute la particularité de la situation de l'auteur dans le cours de la modemité esthétique.

17 Voir notamment Sigmund Freud, "On Narcissism, an Introduction", ainsi que "One of the Difficulties of Psychoanalysis", in Collected Papers, vol. IV, London, The Hogart Press, 1950, p. 30-59, 347-356. Voir également l'introduction que signe Janet Hobhouse à la deuxième autobiographie de Stein, Everybody's Autobiograpby, où elle relève: "In short, the greater the expression of Self in this autobiography, the smaller the expression of ego", Everybody'Autobiography, op. cit., p. xiii. 
paranoïa), il n'en demeure pas moins une des phases essentielles du développement du "soi"17. Dans une direction complémentaire mais plus sociologique, G. H. Mead a ainsi contribué à montrer la place de l'uautrui généralisé " dans la constitution du "soi" au sein de la relation dialectique entre le "je" et le "moi", relation qui s'étend donc entre le niveau singulier de l'organisme individuel et le niveau général de la société ${ }^{18}$.

Ce dépassement de l'égoïsme qui reconnaît dans le "soi " la place de l'altérité, Stein en fait l'expérience dans sa propre conception du génie. L'autodésignation de ce "type "d'individualité dans laquelle Stein se reconnaît signifie ainsi davantage qu'un culte du "moi", car elle rassemble en réalité toute la problématique du "soi" dans une situation où est révélée la consistance ontologique de l'acte poiétique:

[...] the essence of being a genius is to be able to talk and listen to listen while talking and talk while listening but and this is very important indeed talking has nothing to do with creation. ${ }^{19}$

Le génie n'est plus seulement ici, comme dans son acception kantienne, "[...] le talent (le don naturel) de donner à l'art ses règles", ni même, selon son acception hégélienne, "[...] le rapport avec le génie national et les dispositions naturelles d'un peuple" établi dans la subjectivité de l'artiste ${ }^{20}$, mais bien l'intégration de ces deux ordres de critères dans une unité supérieure qui rassemble alors des moments en apparence totalement antinomiques que sont le parler (talking) et l'écouter (listening), l'expression et l'impression ${ }^{21}$. C'est cette expérience de totalisation qui devient

18 Voir la théorisation du "soi " chez G. H. Mead, Mind, Self, Society, Chicago, University of Chicago Press, 1963 (1934), p. 135-226.

19 «[...] l'essence d'être un génie est d'être capable de parler et d'écouter en parlant, et de parler en écoutant, mais cela est très important, en effet parler [seulement] n'a rien à voir avec la création", "What Are Master-Pieces and Why there Are so Few of Them", op. cit., p. 84. Je me permets de modififer la ponctuation et de mettre une certaine insistance entre les crochets là où elle doit être sentie, conformément à ce qui a été vu plus haut.

20 Kant, Critique de la faculté de juger, Paris, Gallimard, 1985, p. 261; Hegel, Estbétique, t. 1, Paris, Flammarion, 1979, p. 357-358.

21 Stein intègre les deux acceptions du génie, c'est-à-dire qu'elle reconnaît à la fois l'entière autonomie de la subjectivité artistique dans l'invention des règles de l'art (voir notamment à ce sujet son essai "Poetry and Grammar", in Gertrude Stein, Lectures in America, New York, Random House, 1935, p. 207-246), ainsi que la définition tout aussi complète de sa propre subjectivité en tant qu'américaine dépendant de ce lien du génie à l'esprit national 
le lieu propre de l'esthétique; or parce qu'elle se pose toutefois expressément dans une mise en cause simultanée des deux pôles de l'échange dialogal (parler et écouter), de même qu'elle prend forme à l'intérieur d'une relation dialogique où se répondent, dans le "soi", le "moi" et l'"autre", cette expérience est avant tout celle de l'expérience symbolique de la communication.

\section{La communication comme expérience cinesthésique}

Cette expérience de totalisation de la communication est celle qui se réalise (ou tente de se réaliser), notamment dans The Making of Americans. Là en effet est déployé le projet d'écriture de tout le monde, c'est-à-dire de la totalité des individus réfléchie dans une histoire, typiquement américaine, cette histoire même que se propose d'être The Making of Americans: "Sometime there will be then such a history of everyone who ever was or is or will be living..." ${ }^{22}$ Ce qui est à l'œuvre ici, c'est cette situation d'écoute et de parole qui, définissant le génie, définit simultanément l'œuvre de la création esthétique. Par celle-ci en effet, tout est transfiguré. Tout individu devient partie d'une écriture qui transforme son être ${ }^{23}$. La totalisation de l'expérience est écriture,

(elle écrit ainsi par exemple: "After all genius has to be made in a country which is forming itself to be what it is..." Gertrude Stein, Everybody's Autobiograpby, op. cit., p. 74). Nous reviendrons plus bas sur cette question cruciale de l'américanité de Gertrude Stein.

22 "Une fois il y aura alors une telle histoire de tout être qui a été, qui est ou qui sera vivant... ", The Making of Americans, New York, Harcourt Brace and Co., 1934, p. 123. Stein poursuit: "[...] and this is not for everybody's reading, this is to give to everybody in their living the last end to being, it makes it so of them real being, it makes for each one who ever is or was or can be living a real continuing.... (Ibid., p. 123-124)

23 Stein précise la situation qui conduit éventuellement à ce projet: "I always as I admit seem to be talking but talking can be a way of listening that is if one has the profound need of hearing and seeing what every one is telling. [...] When I was young and I am talking of a period even before I went to college part of this talking consisted of a desire not only to hear what each one was saying in every way everybody has of saying it but also then of helping to change them and to help them change themselves. I was very full of convictions in those days and I at that time thought that the passion I had for finding out by talking and listening just how everybody was inside them that made them that one, that this passion for knowing the basis of existence in each one was in me to help them change themselves to become what they should become." Gertrude Stein, "The Gradual Making of the Making of Americans ", Lectures in America, op. cit., p. 135-136. 
au sens où celle-ci est communication, mise en relation (dans le double sens du terme: le fait de relater, ainsi que de mise en rapport) de tout être vivant.

La création esthétique (et en particulier ici l'écriture) qui est le propre du génie, se constitue bien dans le domaine des sens (sensations), ainsi que dans son lien au sens (signification); la littérature et la création littéraire sont, profondément, et dans la mesure où prend corps en elles un jeu de formation et de transformation de la perception, expérience esthésique ${ }^{24}$. Or chez Stein cette question est directement saisie comme étant au cœur de la création; si c'est le temps qui est le lieu véritable où s'opèrent formation et transformation du (des) sens, c'est lui qui est également à la fois milieu et matière de la création. Cela explique notamment le caractère totalement différent et pourtant parfaitement similaire de la composition à travers les générations; toujours la même, mais jamais semblable ${ }^{25}$.

Cette question du temps de la composition et du temps dans la composition, posée dans une réflexion sur la création, est à l'œuvre en fait au sein de l'écriture de Stein dans la notion de continuous present (le "présent continu"). C'est elle qui a motivé l'écriture de The Making of Americans, et ce que Stein cherche avant tout à reproduire dans cet ouvrage n'est pas le temps perçu abstraitement, mais bien celui perçu par les sens dans l'espace (sous sa forme d'action, ou plutôt de mouvement). C'est donc la conjonction du temps et de l'espace dans le mouvement devenant ici objet esthétique, c'est-à-dire objet qui peut être à la fois chose représentée, et par la solidarité de la composition à son endroit,

24 Voir à ce sujet Pierre Ouellet, Voir et savoir. La perception des univers $d u$ discours, Candiac, Les Éditions Balzac, 1992, en particulier le chapitre 2, "L'esthésis. Littérature et cognition", p. 165-183.

25 "The only thing that is different from one time to another is what is seen and what is seen depends upon how everybody is doing everything. This makes the thing we are looking at very different and this makes what those describe it make of it, it makes a composition, it confuses, it shows, it is, it looks, it likes it as it is, and this makes what is seen as it is seen. Nothing changes from generation to generation except the thing seen and that makes a composition. [...] It is understood by this time that everything is the same except composition and time, composition and the time of the composition and the time in the composition. Everything is the same except composition and as the composition is diffent and always going to be different everything is not the same." Gertrude Stein, "Composition as Explanation", in What are Masterpieces?, op. cit., p. 26-34. 
chose représentante, que peut en d'autres termes apparaitre le temps (le temps de la composition et le temps dans la composition) comme phénomène esthétique. L'expérience esthésique est en définitive celle du mouvement: elle est en fait pour cela, plus précisément, expérience cinestbésique.

C'est dans ce sens que l'écriture de Gertrude Stein s'approche de la peinture de Picasso; le cubisme de l'un et de l'autre reprennent à leur compte cette exigence fondamentale d'expression du mouvement, d'une manière quelque peu analogue, comme on l'a souvent souligné, à ce que fait le cinéma ${ }^{26}$. Stein elle-même ne s'y trompe pas, mais elle insiste pour relever le fait que la définition de cette expérience cinesthésique a avant tout pour fonction de permettre une immersion plus complète dans le présent des choses, qui sont ainsi animées d'un mouvement situant leur singularité. Sans cette singularité, il n'y a que répétition. Or l'originalité de la création des choses dans l'activité esthésique réfléchit l'originalité même des choses à travers leur représentation esthétique; le mouvement qui transparaît dans l'expérience cinesthésique, telle qu'elle le "traduit", n'est pas répétition (ou imitation) mais plutôt insistance sur les choses (création) ${ }^{27}$. Dans

26 Voir W. Sypher, Rococo to Cubism in Art and Literature, op. cit., p. 266-267, ainsi que E. E. Berry, Curved Thought and Textual Wandering, Ann Arbor, The University of Michigan Press, 1992, particulièrement le chapitre 6: "Modernism/Mass Culture/Postmodernism: The Case of Gertrude Stein", p. 133-152. Cette exigence de concevoir esthétiquement le mouvement, c'està-dire de le représenter, me semble procéder pour la modernité esthétique de la même exigence posée pour le concept dans la philosophie de Hegel. Voir à ce sujet Herbert Marcuse, L'ontologie de Hegel et la théorie de l'bistoricité, Paris, Minuit, 1972.

27 Stein écrit à ce sujet: "As I say I felt the existence of anybody later as I felt the existence of anybody or anything, there was the listening and talking which I was doing which anybody was doing and there the little things that made of any one some one resembling some one. Any one does of course by any little thing by any little way by any little expression, any one does of course resemble some one, and any one can notice this thing notice this resemblance and in so doing they have to remember some one and this is a different thing from listening and talking. In other words the making of a portrait of any one is as they are existing has nothing to do with remembering anyone or anything. Do you see my point, but of course yes you do. You do see that there are two things and not one and if one wants to make one portrait of some one and not two you can see that one can be bothered completely bothered by this thing. As I say it is something that has always bothered anyone. Funnily enough the cinema has offered a solution of this thing. By a continuous moving picture of any one there is no memory or any 
la mesure où cette expérience cinesthésique peut être comprise dans un "espace de temps" donné traduisant l'exigence esthétique propre à la civilisation de notre temps, il s'agira pour Gertrude Stein de la marque qui constitue essentiellement l'américanité de son projet d'écriture:

It is singularly a sense for combination within a conception of the existence of a given space of time that makes the American thing the American thing, and the sense of this space of time must be within the whole thing as well as in the completed whole thing. I felt this thing, I am an American and I felt this thing, and I made a continuous effort to create this thing in every paragraph that I made in The Making of Americans. And that is why after all this book is an American book, because this thing is an essentially American thing this sense of a space of time and what is to be done within this space of time not in any way excepting in the way that it is inevitable that there is this space of time and anybody who is an American feels what is inside this space of time and so well they do what they do within this space of time, and so ultimately it is a thing contained within. ${ }^{28}$

L'expérience cinesthésique est en coüncidence avec la totalité du monde saisie comme "espace de temps", une totalité réfléchie de façon singulière dans l'américanité du projet que Stein poursuit à travers sa création. L'expérience symbolique de la communication, qui constitue le génie dans cette création, qui définit la chose esthétique et l'acte qui la crée

other thing and there is that thing existing, it is in a way if you like one portrait of anything not a number of them. There again you see what I mean", "Portraits and Repetition", in Lectures in America, op. cit., p. 175-176.

28 "C'est singulièrement un sens de la combinaison dans une conception de l'existence d'un espace de temps donné qui fait de la chose américaine une chose américaine, et le sens de cet espace de temps doit être dans toute la chose ainsi que dans toute la chose complétée. Je sentais cette chose, je suis Américaine et je sentais cette chose, et je faisais un effort continu pour créer cette chose dans chaque paragraphe de The Making of Americans. Et c'est pourquoi ce livre après tout est un livre américain un livre essentiellement américain, parce que cette chose est une chose essentiellement américaine, ce sens de l'espace de temps et ce qu'il y a à faire dans cet espace de temps sans rien excepter dans le sens qu'il est inévitable qu'il y ait cet espace de temps et quiconque est Américain sent ce qu'il y a à l'intérieur de cet espace de temps et si bien font-ils ce qu'ils font dans cet espace de temps, si bien ultimement c'est une chose contenue à l'intérieur." Gertrude Stein; "The Gradual Making of the Making of Americans", op. cit., p. 160. 
complètement, dans sa totalité, devient ainsi une cinesthésie de l'américanité29.

\section{Civilisation et histoire: l'identité « réelle » dans l'autobiographie}

Ce fait est paradoxal à plusieurs égards; il pose en définitive une identité à l'intérieur du mouvement qui est précisément, en tant que création vivante et originale, refus de l'identité; il relate, en tant que récit, une bistoire qui ne peut être l'histoire; enfin, il réfléchit le "soi" dans un rapport d'universelle singularité, sans plus aucune apparence de dédoublement. C'est pourtant alors en poussant le paradoxe jusqu'à la contradiction que l'on saisit le mieux la possibilité du "récit de soi "qui émerge chez Gertrude Stein de son impossibilité première.

Bien sûr cette cinesthésie de l'américanité qui constitue le projet esthétique de Stein rencontre éventuellement, une fois qu'il a déterminé sa position d'élocution dans le procès de communication qu'il instaure, ce "soi" qu'il a contribué à former; dans ce sens ce projet sera totalement américain. Il participe même d'un impérialisme propre aux États-Unis d'Amérique, de ce $\mathrm{xx}^{\mathrm{e}}$ siècle qui est, comme Stein le reconnaissait, profondément américain. Gertrude Stein, au même titre que ses prédécessseurs (Whitman, Thoreau), développe ainsi une figure emblématique, sur le mode "prophétique", de ce qu'est, dans son âge impérial, l'être américain ${ }^{30}$. Elle participe pleinement de cette américanité, et cela d'abord parce qu'elle y voit l'identité du Nouveau Monde ${ }^{31}$. Le point de vue qu'elle adopte est donc celui de la création de la "nouvelle civilisation", celle-là même qui est à l'image de la

29 J'ai examiné par ailleurs d'autres aspects de cette question, dans un article à paraître: Jean-François Côté, "Le rêve américain et sa réalité cinématique", Société, $\mathrm{n}^{\mathrm{OS}} 12-13$, automne 1993.

30 Voir notamment à ce sujet G. T. Couser, American Autobiography. The Propbetic Mode, Amherst, University of Massachusetts Press, 1979, p. 14́8163.

31 "It has always seemed to me a rare privilege, this, of being an American, a real American, one whose tradition it has taken scarcely sixty years to create. We need only realise our parents, remember our grandparents and know ourselves and our history is complete. The old people in a new world, the new people made out of the old, that is the story that I mean to tell, for that is what really is and what i really know." Gertrude Stein, The Making of Americans, op. cil., p. 3. 
société américaine, de sa production et de sa consommation de masse, de l'automobile, de la communication. Cette "nouvelle civilisation" est américaine, si américaine dans son origine qu'elle fait même des États-Unis, aux yeux de Stein, le plus vieux pays du monde:

I said that I had begun by saying that after all to-day, America was the oldest country in the world and the reason why was that she was the first country to enter into the twentieth century. She had her birthday of the twentieth century when the other countries were still all in the nineteenth century or still further back in other centuries [...], so that considering the world as twentieth century America is the oldest as she came into the twentieth century in the eighties before any other country had any idea what the twentieth century was going to be. ${ }^{32}$

Cette situation de "création" (à la fois civilisationnelle et artistique, ou en un mot: esthétique), on le voit, se contredit ellemême; en étant obligée en effet de se compter déjà comme étant "vieille", de se raconter, de s' historiciser", au même titre que tout autre "civilisation", l'Amérique de Stein incarne non plus une "entité" originale, mais bien une identité. Et cette identité civilisationnelle, à laquelle s'associe Stein, contredit l'essence même de son propre projet esthétique ${ }^{33}$.

32 "J'ai dit que j'avais commencé par dire qu'après tout, aujourd'hui, l'Amérique est le plus vieux pays du monde et que la raison en était qu'elle fut le premier pays à entrer dans le vingtième siècle. Elle eut son anniversaire du vingtième siècle alors que les tous les autres pays étaient encore au dixneuvième ou plus loin derrière encore dans les siècles [...] et, en considérant le monde comme le vingtième siècle, l'Amérique est le plus vieux pays car elle arriva au vingtième siècle dans les années [dix-huit-cent-] quatre-vingt, avant que tout autre pays ait une idée de ce qu'allait être le vingtième siècle. "Gertrude Stein, "Wars I Have Seen", in Selected Writings of Gertrude Stein, op. cit., p. 704.

33 Et cela dans le sens très précis où ce projet se forme dans la tension entre deux civilisations. Stein écrit à ce sujet: "America is my country and Paris is my home town and it is as it has come to be. After all anybody is as their land is and air is. [...] And so I am an American and I have lived half my life in Paris, not the half that made me but the half in which I made what I made. [...] It has always been true of all who make what they make come out of what is in them and have nothing to do with what is inevitable that they have always wanted two civilizations. The Renaissance needed the greeks, and the modern painter needed the negroes as the English writers have needed Italy and as many Americans have needed Spain or France. [...] What is the difference between romantic and historical. That is very 
128

Gertrude Stein n'avait pas choisi par hasard son exil à Paris qui lui permit, comme elle le croyait fermement, de se créer ellemême. Elle avait éminemment besoin de ce retranchement à l'extérieur pour parvenir à être elle-même, à (se) créer, à (se) découvrir quelque chose comme une intériorité, ce qui n'était tout simplement pas possible pour elle aux États-Unis ${ }^{34}$. De ce point de vue d'où serait issu spécifiquement l'bermétisme propre à ses premiers écrits, de cette situation-limite de communication qu'elle reconnaitrait éventuellement comme étant le propre du génie, elle pouvait élaborer un projet esthétique qui contredisait d'abord de façon radicale les exigences du "monde de la communication". Au sein de ce dernier en effet, et comme elle le soulignait à un certain moment, le déferlement des moyens de communication banalise tout événement, rend tout le monde indifférent, et fait de l'écriture (journalistique, biographique, et même autobiographique) une entreprise tout à fait inintéressante:

The tradition has always been that you may more or less describe the things that happen but nowadays everybody all day long knows what is happening and so what is happening is not really interesting, one knows it by radios cinemas news-

important because that determines which civilization which second civilization you will need in your business as a creator. Historical is different from romantic and to us Americans England is historical while France and Spain are romantic. [...] History is what happened and so having happened and so having happened it is something that might happen and so does not exist for and by itself and is therefore not romantic. This is all really very exciting, and you see the trouble is that now the world is very small, history that is anything happening goes on, and the difference between writing and speaking is nothing well then where are we, where are we to find two civilizations which I insist any one creating anything needs to have if he is to create anything." Gertrude Stein, "An American and France", What Are Master-Pieces?, op. cit., p. 61-62, 63, 65-66.

34 "To be friendly and to let you alone, to be there and to be not needed by it, that was France in the nineteenth century and so everybody was there and everybody and anybody did what they did in it not being of it because one could not be of it since it was there. [...] It is not what France gave you but what it did not take away from you that was important. "Gertrude Stein, "An American and France", What Are Master-Pieces?, op. cit., p. 70. C'est cette impossibilité pour les Américains de se constituer une intériorité aux ÉtatsUnis qui frappe Stein lors de son tour de conférences en 1934-1935. Elle remarque en effet qu'aux États-Unis "everybody is a public something" (Gertrude Stein, Everybody's Autobiograpby, op. cit., p. 157, et aussi 183.) Voir également à ce sujet J. G. Kennedy, Imaginig Paris. Exile, Wrinting, and American Identity, New Haven, Yale University Press, 1993, p. 1-78. 
papers biographies autobiographies until what is happening does not really thrill them. The painter can no longer say that what he does is as the world looks to him because he cannot look at the world any more, it has been photographed too much and he has to say that he does something else. ${ }^{35}$

Les tentatives d'autobiographie de Gertrude Stein prennent donc dans ce contexte un relief particulier; lorsqu'est devenu possible le "récit de soi ", lorsque la relation qui le constitue s'est fait jour, lorsque surtout l'altérité intériorisée par le "moi" est devenue, par le biais de la publication, une altérité extérieure, un public à même de (re)constituer l'identité d'origine du récit, le génie, rendu impossible dans ces conditions, a disparu. Dans sa reconnaissance extérieure, son intériorité propre s'est volatilisée. Il est devenu quelqu'un, une intériorité révélée, une identité (comme une autre) dans une histoire. La narration fictionnelle a ainsi contribué seulement à faire de la "connaissance de soi", dans ce qu'elle ne peut toujours qu'être incomplète tant sur le plan narratif que sur le plan existentiel, un "apprentissage du mourir" 36 .

"[...] I am certain that what makes American success is American failure", répète à quelques reprises Stein ${ }^{37}$. Et l'écriture de soi qui rend compte de cette possibilité du génie américain,

35 "La tradition fut toujours que vous pouviez plus ou moins décrire les choses qui arrivent mais aujourd hui tout le monde à longueur de journée sait ce qui arrive et ainsi ce qui arrive n'est pas vraiment intéressant, on le sait par la radio le cinéma les journaux les biographies les autobiographies jusqu'à ce que ce qui arrive ne transporte plus vraiment personne, cela les excite un peu mais ne les transporte pas vraiment "Gertrude Stein, "What Are Masterpieces and Why Are There so Few of Them", in What Are MasterPieces and Why Are There so Few of Them?, op. cit., p. 87.

36 Paul Ricœur, Soi-même comme un autre, op. cit., p. 192. Ricœur écrit: "Quant à ma mort, elle ne sera fin racontée que dans le récit de ceux qui me survivront; je suis toujours vers ma mort, ce qui exclut que le je la saisisse comme fin narrative." (Ibid., p. 190).

37 "Je suis certaine que ce qui fait le succès américain est l'échec américain", Gertrude Stein, Lectures in America, op. cit., p. 172. Cette situation se réfère directement au projet d'écriture de Stein; elle écrit par exemple: "And if you stop writing if you are a genius and you have stopped writing are you still one if you have stopped writing. I do wonder about that thing. [...] When a genius gets older is there less of it and does it then not worry him. Not always. Some have stooped, the few there are, others have gone on them. I used to be fond of saying that America which was supposed to be a land of success was a land of failure, most of the great men in America, had a long life of early failure and a long life of later failure", Gertrude Stein, Everybody's Autobiograpby, op. cit., p. 68-69. 
130

de son destin particulier chez Gertrude Stein, me paraît être cela même qui situe simultanément l'impossibilité de son récit autobiographique. 